\title{
THE RENAL EXCRETION OF CREATININE IN MAN
}

\author{
By JAMES A. SHANNON 1 \\ (From The Department of Physiology, New York University College of Medicine, \\ New York City)
}

(Received for publication March 27, 1935)

In a previous paper the evidence on the excretion of carbohydrates by the toadfish, goosefish, dogfish, dog and man was reviewed and it was concluded that, until evidence to the contrary is adduced, all the available facts are best interpreted on the supposition that pure carbohydrates in general are not secreted by the renal tubules of any of the above-mentioned forms (Shannon and Smith, 1935).

The evidence on creatinine points in the contrary direction. Although this substance is not normally present in significant quantities in the urine of aglomerular fishes, administered creatinine is copiously excreted by the toadfish and the goosefish (Marshall, 1930, 1934). Marshall and Grafflin (1932) have shown in the toadfish that the quantity of creatinine excreted per unit time does not increase in direct proportion to the quantity injected into the body. This failure to obtain direct proportionality between the quantity of substance administered and the rate of its excretion was first described for any substance by Marshall and Crane (1924) in their examination of the excretion of phenol red by the dog, and these investigators pointed out that the observed curvilinear relationship between plasma level and rate of excretion was incompatible with excretion by exclusive filtration. A similar phenomenon has subsequently been shown by Bieter (1933) and Marshall and Grafflin (1932) to occur in the excretion of phenol red in the toadfish.

An analysis of the simultaneous excretion of creatinine and xylose (or sucrose) in the dogfish by Shannon (1934a) has disclosed that the creatinine clearance at low plasma levels of this substance is from 4.2 to 7.2 times as large as is the simultaneous xylose clearance. As the plasma level is raised the creatinine clearance is depressed, both absolutely and relative to the clear-

1 This paper is based on a thesis to be presented to the Graduate School of New York University in partial fulfillment of the requirements for the degree of Doctor of Philosophy. ance of the sugar, until at plasma levels of 140 mgm. per cent the creatinine/sugar clearance ratio is less than 2. Entirely similar results have been obtained more recently in a comparison of the creatinine clearance with the inulin clearance (Shannon, 1934b). Phlorizin lowers the creatinine clearance both absolutely and relative to the sugar clearance, as first described by Clarke and Smith (1932), who ascribed this result to a depressing action of this drug on the secretory power of the tubules.

MacKay (1929-30) has shown in one individual that, under controlled conditions in man, the rate of excretion of creatinine is directly proportional to plasma concentrations up to $15 \mathrm{mgm}$. per cent; and Cope (1931) has obtained a similar result in another individual up to $8 \mathrm{mgm}$. per cent. We have not reexamined the matter within this range, but the above data, combined with those of Jolliffe and Chasis (1933) who worked between 2.4 to $11.6 \mathrm{mgm}$. per cent in one instance, and 1.8 to $7.0 \mathrm{mgm}$. per cent in a second, would seem to indicate that in man proportionality between plasma level and rate of excretion holds up to $10 \mathrm{mgm}$. per cent. This point will be discussed later.

The present paper reports observations on the excretion of creatinine in relation to higher plasma concentrations in man, and the comparison of creatinine clearances with simultaneous inulin clearances (see Shannon and Smith (1935)). The experimental procedure is identical with that described by Shannon and Smith, and in fact many of the creatinine observations were made at the same time when the other clearances described in that paper were measured. The subjects were volunteers from the wards of the Third Medical Division of Bellevue Hospital, without history or present evidence of renal pathology, having been admitted for entirely' minor complaints.

We find in man, as in the dogfish, that as the plasma concentration is progressively raised above 
$10 \mathrm{mgm}$. per cent there is a reduction in the creatinine clearance. Since this reduction might be due to a reduction in the rate of filtration, it is necessary to have information on the simultaneous clearance of some other substance. For this reason we have included inulin clearances which, according to the available evidence, are close to the glomerular level (Shannon and Smith (1935)). Because of the spontaneous variations in renal activity that are known to occur in man as well as in other mammals, and because of the variations in renal activity in different individuals, it is convenient to express the results in terms of the creatinine/inulin clearance ratio. It should be noted, however, that in the present series of observations there has been little change in the inulin clearance in any one experiment.

Data illustrating the effects of raising the plasma concentration of creatinine upon the creatinine clearance are given in Table I. In Figures 1 and 2 are given additional data on the creatinine/inulin clearance ratios in two individuals in whose plasma the concentration of creatinine was raised from 5 to $10 \mathrm{mgm}$. per cent to intermediate, and then to high level, by two intravenous infusions of this substance. Each open circle represents the average of the creatinine/in- ulin clearance ratio in 3 successive clearance determinations, each clearance determination being based on a urine collection period of 10 to 20 minutes. The open circles connected by a line represent successive observations made on one day. The change in creatinine/inulin clearance ratio is due to variation in the clearance of creatinine rather than that of inulin. The inulin clearance is, in fact, quite independent of the immediate plasma level of the substance, as was shown by Shannon and Smith (1935), as well as being independent of the initial plasma level. For example, in one individual (W. F.) the inulin clearance varied only from 73 to 80 when the initial plasma level of inulin obtained on six separate occasions varied from 175 to $415 \mathrm{mgm}$. per cent, and in another individual (J. S.) the clearance remained constant at 140 in two groups of observations in which the initial inulin plasma level was 115 and $400 \mathrm{mgm}$. per cent. These points are further substantiated by the summarizing data given in Table II.

At low plasma concentrations of creatinine (7.3 to $13 \mathrm{mgm}$. per cent) the creatinine clearance is from 30 to 45 per cent higher than the inulin clearance, the mean value being 1.39 . This corresponds to a creatinine/xylose clearance ratio of

TABLE I

Typical protocol of observations on $J . C$. showing depression of creatinine clearance resulting from raising plasma creatinine concentration. May 25, 1934. S.A. = $1.63 \mathrm{sq.} \mathrm{m}$.

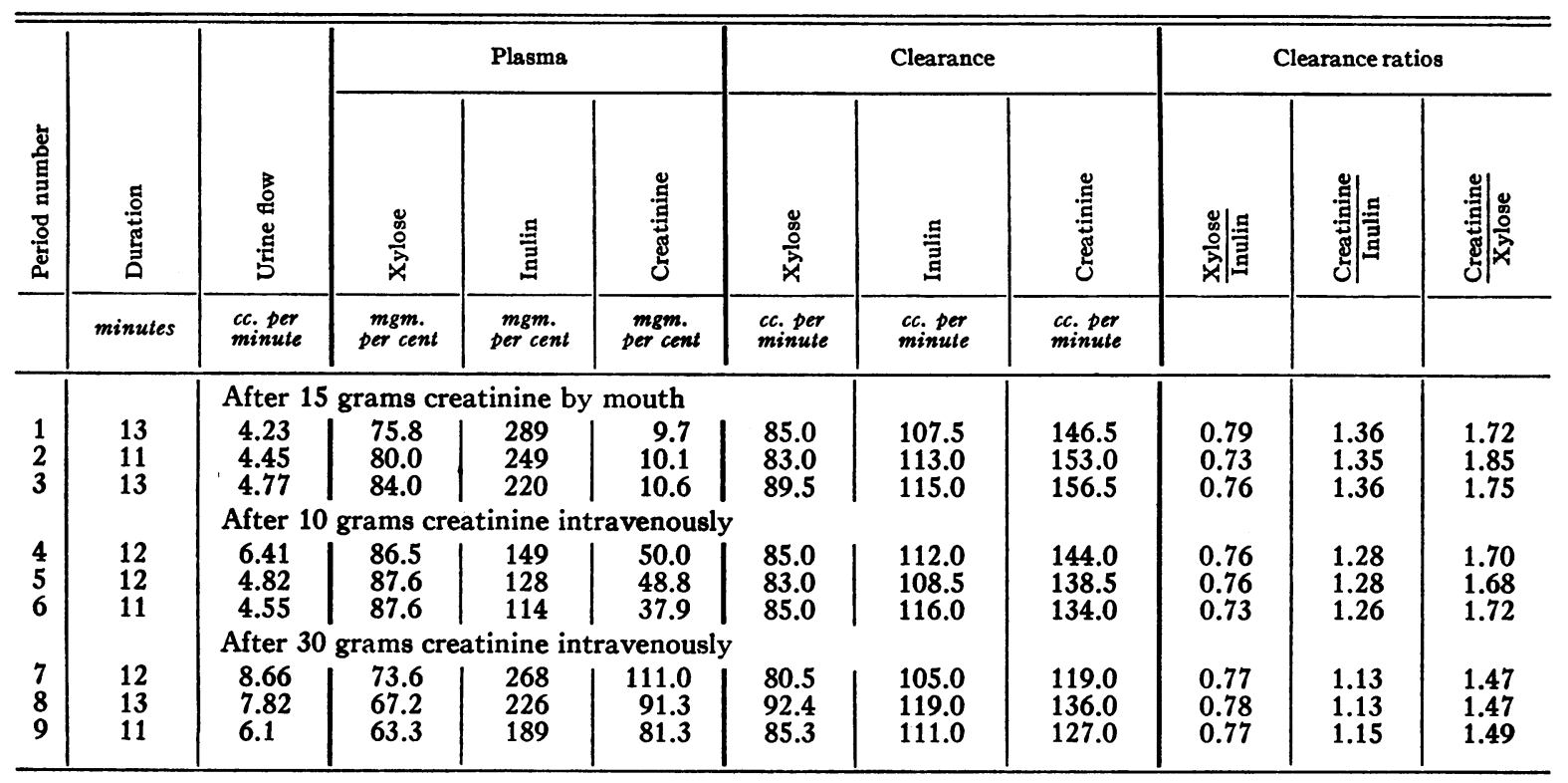




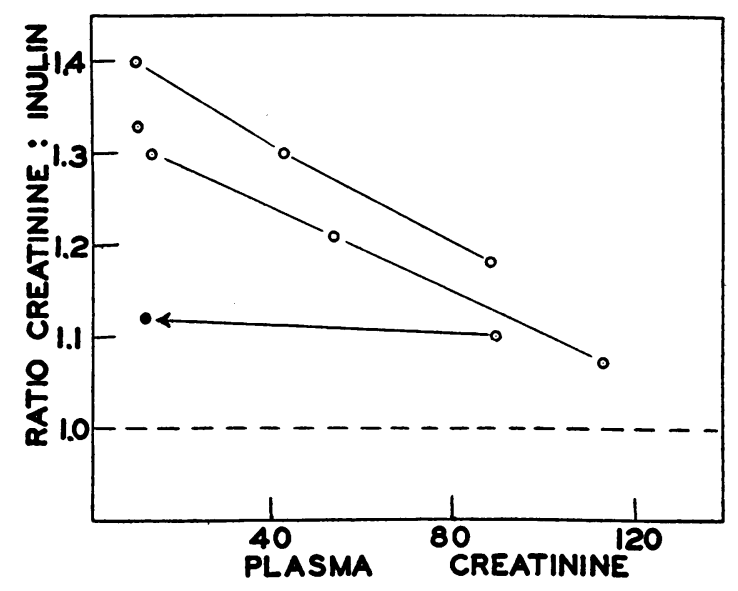

FIG. 1

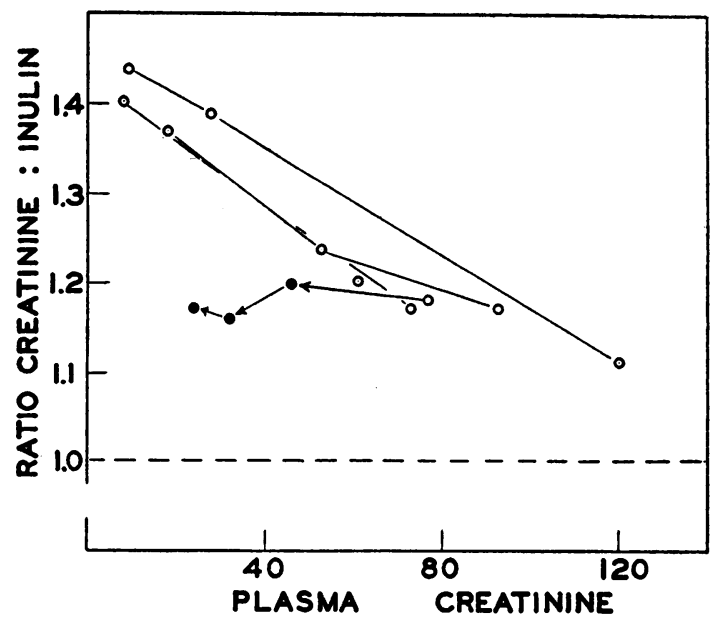

FIG. 2

Figs. 1 and 2. The Excretion of Creatinine in Relation to Plasma level.

The ratio of the creatinine clearance divided by the simultaneous inulin clearance is plotted against the plasma concentration of creatinine in mgm. per cent. The open circles each represent the average of 3 clearance periods, observed in the order of increasing plasma concentration. The solid dots represent the average of 3 clearance periods when they are observed after the plasma concentration has been raised and allowed to fall again. Points connected by lines represent observations on a single individual in one day.

TABLE II

Summary of absolute clearances on $W . F$. and $S . C$. showing that the variation in the creatinine/inulin ratio is due to changes in the absolute creatinine clearance, the inulin remaining essentially constant: these clearances are those represented as open circles in Figures 1 and 2.

\begin{tabular}{|c|c|c|c|c|c|c|}
\hline & $\begin{array}{l}\text { Number of } \\
\text { observations }\end{array}$ & Plasma & $\begin{array}{c}\text { Average } \\
\text { clearance }\end{array}$ & $\begin{array}{l}\text { Number of } \\
\text { observations }\end{array}$ & Plasma & $\begin{array}{c}\text { Average } \\
\text { clearance }\end{array}$ \\
\hline Inulin & $\begin{array}{r}2 \\
7 \\
10 \\
11\end{array}$ & $\begin{array}{c}\text { mgm. per cent } \\
>400 \\
301-400 \\
201-300 \\
<201\end{array}$ & $\begin{array}{c}\text { cc. per minute } \\
80 \\
76 \\
75 \\
77\end{array}$ & $\begin{array}{l}6 \\
8 \\
7 \\
3\end{array}$ & $\begin{array}{c}\text { mgm. per cent } \\
>300 \\
201-300 \\
101-200 \\
<101\end{array}$ & $\begin{array}{c}\text { cc. per minute } \\
114 \\
109 \\
97 \\
109\end{array}$ \\
\hline Creatinine & $\begin{array}{l}5 \\
6 \\
7 \\
6 \\
6\end{array}$ & $\begin{array}{r}>91 \\
71-90 \\
41-70 \\
21-40 \\
1-10\end{array}$ & $\begin{array}{r}80 \\
90 \\
91 \\
105 \\
112\end{array}$ & $\begin{array}{l}3 \\
6 \\
5 \\
7 \\
3\end{array}$ & $\begin{array}{r}>99 \\
71-99 \\
41-70 \\
12-40 \\
10-11\end{array}$ & $\begin{array}{l}121 \\
116 \\
127 \\
143 \\
164\end{array}$ \\
\hline
\end{tabular}

1.62 to 1.88 , as compared to the average figure of Jolliffe and Chasis (1933) of 1.73. But as the plasma concentration of creatinine is raised the creatinine clearance falls absolutely and relative to the inulin clearance, until at plasma concentrations of 96 to $127 \mathrm{mgm}$. per cent the creatinine clearance exceeds the inulin clearance by a mean of 12 per cent.

It should be noted particularly that the first observations in the series described above were made at low plasma concentrations; an infusion of a moderate amount of creatinine was then given and a second set of 3 clearances was obtained; then, after the infusion of creatinine a second time, a third series of clearances was obtained. This procedure was so standardized that the periods of observation were completed within one hour after the injection of the creatinine.

When the creatinine/inulin clearance ratio is determined on a "falling" blood curve, that is, 
over an extended period of time after the injection of a considerable quantity of creatinine, a different result is obtained. The creatinine/inulin clearance ratio does not retrace the course set on a "rising" plasma curve, but remains at a depressed level for a number of hours, as is indicated by the solid dots in Figures 1 and 2 . (No such phenomenon is observable in the case of inulin as has been pointed out above.) The normal level of creatinine clearance is restored within a few days, but just how fast we have not determined. A search for this phenomenon in the dogfish failed to reveal it; the creatinine clearance rises in this animal, relative to the sugar clearance, as fast as the plasma creatinine falls, so that identical clearances are obtained at low plasma concentrations, before and after the administration of large doses of this substance. But in the dogfish several days are required for the plasma concentration to return to its former level, and it is possible that this time is necessary for the secretory mechanism to return to its initial state (Shannon $(1934 a))$. The practical significance of this delayed recovery needs to be emphasized, since this apparent constancy of the creatinine/inulin clearance ratio when the plasma level of creatinine is falling is also evident in successive periods of urine collection such as have been used in obtaining each point in Figures 1 and 2 . It seems probable, therefore, that our creatinine/inulin clearance ratios, as recorded in these figures, are really too low, being "set" or determined by a plasma level that was initially higher than that actually observed.

The data given in Table I will enable the reader to judge the magnitude and significance of all the terms involved. Xylose has not been present in every instance, but when present there has been no change in the inulin/xylose clearance ratio occasioned by the administration of the creatinine. This fact emphasizes that it is its own clearance that is affected by the administration of creatinine, rather than that of inulin, the clearance of reference.

The question may be raised, to what extent does the excretion of endogenous creatinine enter into the results described above. Table III contains data on the excretion of apparent endogenous creatinine (total chromogenic substance) in
TABLE III

The excretion of endogenous creatinine in man

\begin{tabular}{|c|c|c|c|c|}
\hline \multirow{2}{*}{ Subject } & \multirow{2}{*}{$\begin{array}{c}\text { Number of } \\
\text { periods }\end{array}$} & \multirow{2}{*}{$\begin{array}{l}\text { Average urine } \\
\text { flow }\end{array}$} & \multicolumn{2}{|c|}{$\begin{array}{l}\text { Average apparent } \\
\text { creatinine }\end{array}$} \\
\hline & & & $\begin{array}{c}\text { Plasma } \\
\text { level }\end{array}$ & Clearance \\
\hline $\begin{array}{l}\text { R.C. . } \\
\text { H.S.. } \\
\text { C.C. } \\
\text { B.K. }\end{array}$ & $\begin{array}{l}2 \\
2 \\
2 \\
2\end{array}$ & $\begin{array}{c}\text { cc. per minute } \\
8.4 \\
16.6 \\
9.5 \\
4.0\end{array}$ & $\begin{array}{l}1.44 \\
1.32 \\
1.44 \\
1.70\end{array}$ & $\begin{array}{r}109.0 \\
120.0 \\
134.5 \\
88.5\end{array}$ \\
\hline
\end{tabular}

four normal individuals. The clearance of endogenous creatinine is such that, if a correction were made for it in the data displayed in Figures 1 to 3 , it would raise slightly, but not significantly, both the total creatinine clearance and the creatinine/inulin clearance ratio at low plasma levels, while the correction would have no effect at higher plasma levels.

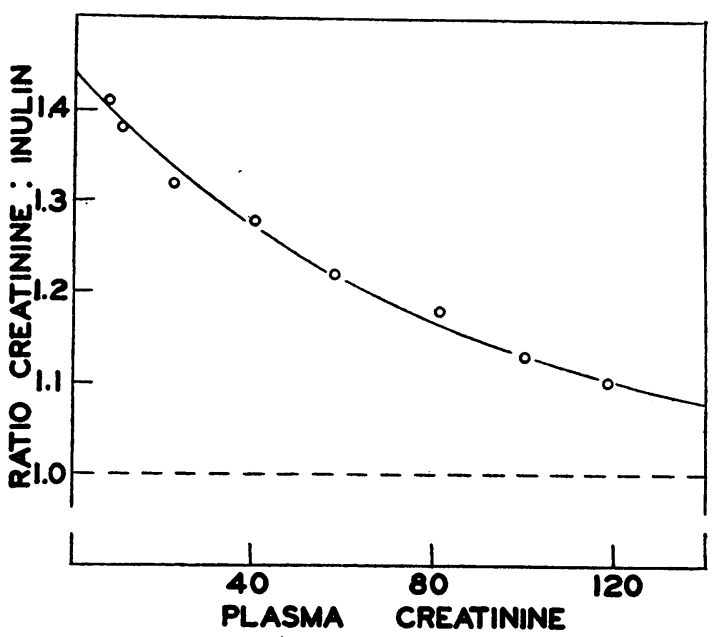

Fig. 3. When 80 Observations on the Creatinine/ Inulin Clearance Ratio Are Averaged in Groups of Ten, Selected in Order of Increasing Plasma Creatinine Concentration, and Plotted Against the Latter, the 8 Points So Obtained Fall Upon a Smooth Curve Which Appears to Be Approaching 1.0 as the AsY MPTOTE.

The curve given in this figure is calculated by the exponential equation described in the legend of Figure 4, and represents the relationship between $1+y$ (creatinine/inulin clearance ratio) and $x$ (plasma creatinine level). This curve indicates that the creatinine clearance is driven down towards the level of the inulin clearance by raising the concentration of creatinine in the plasma at such a slow rate that the asymptote could not be reached in practice. 


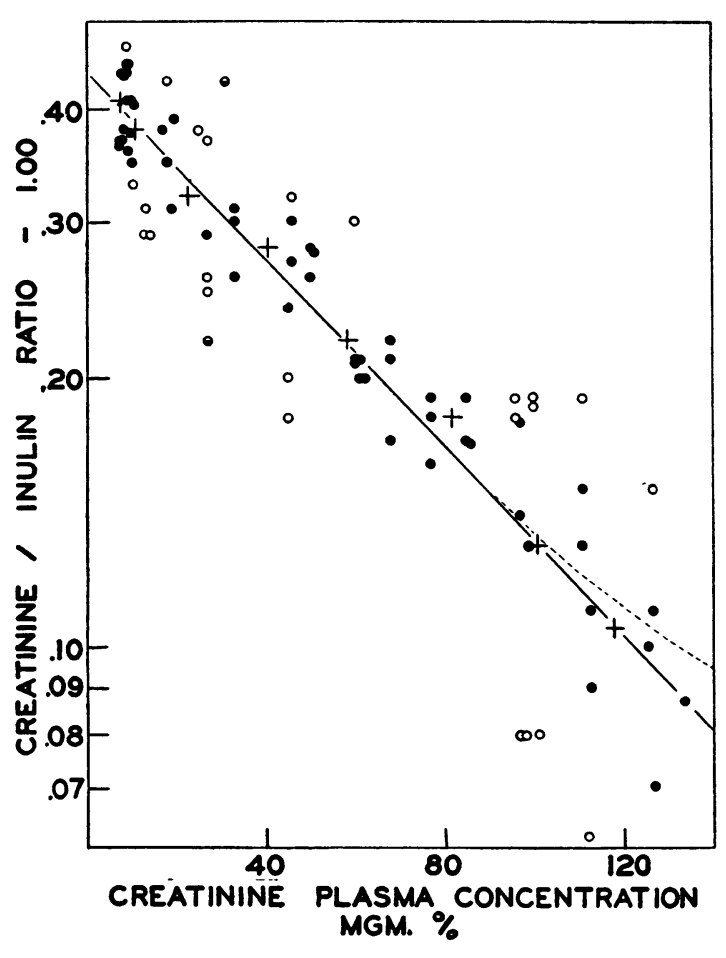

Fig. 4. The Relationship of Creatinine/Inulin Clearance Ratio to Plasma Level of Creatinine as Obtained from 80 Observations Made Under Standardized Conditions as Described in the Text.

When the term, creatinine/inulin $-1.0=(y)$, is plotted against the plasma level of creatinine $(x)$, an exponential relationship of the type $y=a e^{-\alpha x}$ is obtained, where $a$ is the intercept on the $y$ axis (.44) and $\alpha$ is a constant determining the slope of the line (.0122). The solid line indicates the relationship described by the equation, the term $y$ in this figure being plotted on a logarithmic scale.

With regard to this exponential relationship, we note the following: if the term $1+y$, as generated by the above equation, be taken as the mean, and if the standard deviation from this mean be calculated in terms of per cent of the mean, it is found to be 3.6 per cent. All observations fall within 3 times the standard deviation. The agreement is equally good for both the upper and lower portions of the curve. In the figure those points falling within once the standard deviation are indicated by solid dots, those falling within twice the standard deviation by open circles, and those within three times by half-filled circles. The crosses indicate the average data plotted as open circles in Figure 3. When the limitations of experimental and chemical methods are considered, this agreement is as satisfactory as can be expected. So far as the physiological significance of this equation is concerned, perhaps the most noteworthy point is the fact that the quantity of creatinine apparently secreted per minute per 100 cc. glomerular filtrate (inulin clearance) passes through a maximum of $13.3 \mathrm{mgm}$. at a plasma level of
$70 \mathrm{mgm}$. per cent, to decrease at higher plasma levels. If, however, it is supposed that the creatinine apparently secreted per $100 \mathrm{cc}$. glomerular filtrate increases to a maximum and maintains this maximum at plasma levels above 70 per cent, then the relationship would be such as is indicated by the dotted line in the figure. Since the latter possibility does not seem unlikely, it throws doubt upon the physiological significance of the exponential relationship.

In our data there are 80 instances in which the creatinine clearance and creatinine/inulin clearance ratio were determined at two or more widely separated plasma levels of creatinine, and in which the technique was so standardized that the first period of observation was started within 15 to 30 minutes after the completion of the creatinine infusion. From these 80 instances we have constructed an average curve relating creatinine/ inulin clearance ratio to plasma creatinine concentration by averaging each group of ten observations at successively higher plasma levels of creatinine. The average curve (Figure 3 ) thus obtained is smooth and convex to the intersection of the coordinates. It is apparent that the curve does not approach a zero clearance as its asymptote; in our interpretation, this asymptote should be the level of glomerular filtration, which we can take as approximately the inulin clearance. This curve is apparently exponential in character and is discussed in the legend to Figure 4. (In plotting the mass data in this figure, the plasma level obtaining in the first of each group of three observations was taken for all three, since the creatinine clearance is "set" by the highest plasma level obtained.) In view of the general relationship it appears that lowering the plasma level of creatinine from 10 to $0 \mathrm{mgm}$. per cent would have an insignificant effect upon the absolute creatinine clearance (increasing the creatinine/inulin clearance ratio from 1.39 to 1.44 ). This fact may explain why the several observers mentioned above failed to find any relationship between creatinine clearance and plasma creatinine within this range.

\section{Action of phlorizin}

The knowledge that phlorizin depresses the creatinine clearance in the dogfish to levels close to the sugar clearances (Clarke and Smith (1932) ; Shannon $(1934 a, 1934 b))$ has led us to believe that, if the creatinine clearance in excess 
of the inulin clearance in man is really a secretory phenomenon, then phlorizin should produce a similar result in this case. Chasis, Jolliffe and Smith (1933) failed to obtain any significant effect upon the creatinine/xylose clearance ratio in man by the administration in several individuals of amounts of phlorizin up to $20 \mathrm{mgm}$. per kilogram, and in a single instance of $65 \mathrm{mgm}$. per kilogram. A negative result was also obtained by Goldring and Welsh (1934) following the administration of much larger doses of this drug by stomach. Believing that the quantity hitherto administered was short of the required amount, we raised the intravenous dose to $100 \mathrm{mgm}$. per kilogram (see Shannon and Smith (1935)). A summary of all data before and after phlorizin is given in Table IV and Figure 5. All clearances usually fall in consequence of the intravenous administration of phlorizin; this transient depression is apparently circulatory or glomerular in origin, and has been noted by Marshall and Grafflin (1932) in the sculpin, by White and Monaghan (1933) in the dog, and by Chasis, Jolliffe and Smith (1933) and Goldring and Welsh (1934) in man after intravenous and oral administration. Pitts ' (1934) has found that the creatinine (and creatine) clearance in the dog falls after phlorizin, but not the xylose clearance; the creatinine/creatine clearance ratio, however, remains constant. In view of this frequent de-

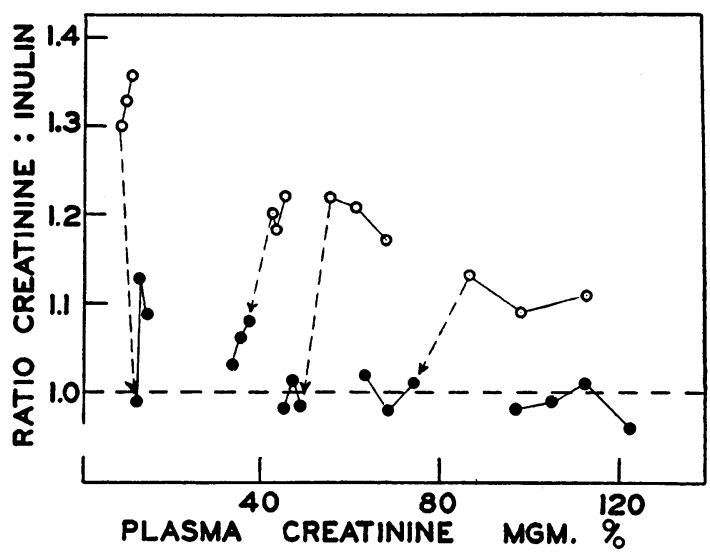

Fig. 5. The Influence of Phlorizin (Solid Dots) in Reducing the Creatinine Clearance to the InUlin Clearance.

Phlorizin was given intravenously (100 $\mathrm{mgm}$. per kilogram) after the 3 control clearances (open circles) were observed.

pression of all clearances, it is impossible to decide from the absolute values of a particular clearance whether the excretion of that substance is specifically affected by the drug. It is none the less significant that, under the action of adequate doses of phlorizin, the creatinine and inulin clearances are brought together perfectly at the high plasma levels of creatinine, if our observations on single individuals are significant, and less perfectly at low plasma levels. Thus, in the data

TABLE IV

Summary of observations of men before and after phlorizin (100 mgm. per kilogram intravenously). Each datum given is the average of 3 clearance periods of 10 to 15 minutes each

\begin{tabular}{|c|c|c|c|c|c|c|c|c|c|c|c|}
\hline \multirow{2}{*}{$\underset{\text { ject }}{\text { Sub- }}$} & \multirow{2}{*}{$\begin{array}{c}\text { Average } \\
\text { urine flow }\end{array}$} & \multirow{2}{*}{$\begin{array}{c}\text { Average } \\
\text { plasma } \\
\text { creatinine } \\
\text { concen- } \\
\text { tration }\end{array}$} & \multicolumn{5}{|c|}{ Average clearances } & \multicolumn{4}{|c|}{ Average clearances/inulin clearance } \\
\hline & & & Urea & Xylose & Inulin & Creatinine & Glucose & Urea & Xylose & Creatinine & Glucose \\
\hline & $\begin{array}{l}\text { cc. per } \\
\text { minute }\end{array}$ & $\underset{\text { per cent }}{m g m .}$ & $\begin{array}{l}\text { cc. per } \\
\text { minute }\end{array}$ & $\begin{array}{l}c c \text {. per } \\
\text { minute }\end{array}$ & $\begin{array}{l}c c . \text { per } \\
\text { minute }\end{array}$ & $\begin{array}{l}c c_{.} \text {per } \\
\text { minute }\end{array}$ & $\begin{array}{l}\text { cc. per } \\
\text { minute }\end{array}$ & & & & \\
\hline S.C. & $\begin{array}{l}4.0 \\
3.1^{*}\end{array}$ & $\begin{array}{r}9.6 \\
12.2\end{array}$ & $\begin{array}{l}63.2 \\
35.6\end{array}$ & $\begin{array}{l}91.7 \\
57.1\end{array}$ & $\begin{array}{r}123.0 \\
66.9\end{array}$ & $\begin{array}{r}163.8 \\
71.6\end{array}$ & 56.2 & $\begin{array}{l}0.514 \\
0.532\end{array}$ & $\begin{array}{l}0.745 \\
0.854\end{array}$ & $\begin{array}{l}1.33 \\
1.07\end{array}$ & 0.840 \\
\hline B.R. & $\begin{array}{l}6.0 \\
4.5^{*}\end{array}$ & $\begin{array}{l}43.7 \\
35.5\end{array}$ & $\begin{array}{l}55.9 \\
47.1\end{array}$ & $\begin{array}{l}69.4 \\
61.7\end{array}$ & $\begin{array}{l}84.1 \\
69.6\end{array}$ & $\begin{array}{r}101.0 \\
73.3\end{array}$ & 61.5 & $\begin{array}{l}0.675 \\
0.677\end{array}$ & $\begin{array}{l}0.826 \\
0.887\end{array}$ & $\begin{array}{l}1.20 \\
1.05\end{array}$ & 0.884 \\
\hline W.F. & $\begin{array}{c}10.9 \\
4.5^{*}\end{array}$ & $\begin{array}{l}61.5 \\
47.2\end{array}$ & $\begin{array}{l}49.6 \\
35.6\end{array}$ & $\begin{array}{l}61.0 \\
51.5\end{array}$ & $\begin{array}{l}75.8 \\
56.3\end{array}$ & $\begin{array}{l}91.1 \\
55.7\end{array}$ & 50.4 & $\begin{array}{l}0.654 \\
0.632\end{array}$ & $\begin{array}{l}0.804 \\
0.916\end{array}$ & $\begin{array}{l}1.20 \\
0.99\end{array}$ & 0.896 \\
\hline J.C. & $\begin{array}{l}4.4 \\
3.7^{*}\end{array}$ & $\begin{array}{l}99.0 \\
68.3\end{array}$ & & & $\begin{array}{l}112.0 \\
100.0\end{array}$ & $\begin{array}{l}125.0 \\
101.0\end{array}$ & & & & $\begin{array}{l}1.12 \\
1.01\end{array}$ & \\
\hline B.R. & $7.4^{*}$ & 109.7 & & 59.5 & 67.8 & 66.6 & 61.0 & & 0.878 & 0.98 & 0.900 \\
\hline
\end{tabular}

* Indicates after phlorizin. 
given in Figure 4 the average creatinine/inulin clearance ratios of 3 clearances after phlorizin are 1.07 at $12 \mathrm{mgm}$. per cent, 1.06 at $36 \mathrm{mgm}$. per cent, 1.00 at $47 \mathrm{mgm}$. per cent, 1.00 at $68 \mathrm{mgm}$. per cent and 0.98 at $109 \mathrm{mgm}$. per cent.

\section{DISCUSSION}

It is clear from the above observations that the creatinine clearance is depressed, both absolutely and relative to the inulin clearance, by an elevation of the plasma concentration of creatinine. This result leads, of course, to a reduction in the rate of excretion relative to plasma level, the phenomenon described in the first part of the paper. As Marshall and Crane (1924) pointed out in their discussion of the excretion of phenol red by the dog, a curvilinear relationship between plasma level and rate of excretion (or, in our present terms, between plasma level and clearance) is incompatible with exclusive filtration. It is conceivable that a substance excreted both by filtration and tubular secretion might display a linear relationship in this respect (as in fact creatinine does when the plasma is falling); but we are unable to imagine any reason why the clearance should decrease with increasing plasma concentration unless secretion is involved. If filtration alone were operative, this result would require that either the quantity of creatinine filtered decreased, or that the relative amount of creatinine reabsorbed (if any) increased, as the plasma level rose. A positive finding of a depression of clearance caused by increased plasma concentration can therefore be taken in our opinion as positive evidence of secretion. We offer this, consequently, as independent evidence of the secretion of creatinine by man.

The nature of the creatinine, excreted in excess of the amount that can be accounted for by glomerular filtration (inulin clearance), is unknown. It might be true creatinine added to the postglomerular filtrate by tubular activity; or it might be a creatinine derivative that gives the Jaffe reaction, formed prior to or during tubular secretion. No method is available at this time to distinguish these possibilities.

Shannon and Smith (1935) have presented evidence that the rate of glomerular filtration lies at least as high as the level of the inulin clearance, but they have pointed out that there is nothing to indicate the absence of active reabsorption of this substance; and in view of the fact that evidence is at hand for the active reabsorption of xylose (and sucrose), such evidence is needed before the active reabsorption of inulin can be ruled out. There is no reason to believe that creatinine would influence either the active reabsorption or the diffusion of inulin, and, in fact, the constancy of the inulin clearance and of the inulin/xylose clearance ratio is substantial evidence that such is not the case. We present the fact that the creatinine clearance can be depressed to within 10 per cent of the simultaneous inulin clearance by the administration of creatinine, as evidence that the rate of glomerular filtration cannot lie higher than 10 per cent above the inulin clearance. It is reasonable to suppose that at the highest plasma levels observed some creatinine is still being secreted and therefore that the rate of glomerular filtration lies nearer the level of the inulin clearance than the lowest level of the creatinine clearance.

The statement in the above paragraph would have to be qualified if creatinine were reabsorbed to any extent. But the fact that phlorizin lowers the creatinine clearance to, but not below, the inulin clearance, indicates that under the conditions of these experiments there is no measurable reabsorption of creatinine, and that the creatinine clearance in phlorizinized man (though only under this condition) is at the level of glomerular filtration.

\section{SUMMARY}

1. When the creatinine concentration of the plasma is raised the creatinine clearance in man is depressed, both absolutely and relative to the simultaneous inulin clearance. At plasma levels of 7.3 to $13.0 \mathrm{mgm}$. per cent the mean ratio of the creatinine clearance over the inulin clearance is 1.39. At plasma levels from 96 to $127 \mathrm{mgm}$. per cent this mean ratio is lowered to 1.12 .

2. The relationship expressed in (1) is believed to be independent evidence of the secretion of creatinine by the renal tubules in man.

3. It is suggested that the level of glomerular filtration in normal man lies between the lowest creatinine clearance and the inulin clearance obtained at high plasma levels of this substance; and 
in view of the fact that at the highest plasma levels observed the creatinine clearance is still unquestionably elevated by secretion, it is probable that the level of glomerular filtration lies closer to the inulin clearance than to the former. This is believed to be independent evidence against any extensive active reabsorption of inulin.

4. Phlorizin administered in doses of $100 \mathrm{mgm}$. per kilogram brings the clearances of creatinine and inulin together, presumably by a specific depressant action on the tubular secretion of the former substance. The identity of these clearances under phlorizin is evidence against the diffusion of creatinine under the conditions of the experiment.

\section{BIBLIOGRAPHY}

Bieter, R. N., Excretion of phenol red by the aglomerular kidney. Proc. Soc. Exper. Biol. and Med., 1933, 30, 981.

Chasis, H., Jolliffe, N., and Smith, H. W., The action of phlorizin on the excretion of glucose, xylose, sucrose, creatinine and urea by man. J. Clin. Invest., 1933, 12, 1083.

Clarke, R. W., and Smith, H. W., Absorption and excretion of water and salts by the elasmobranch fishes. III. The use of xylose as a measure of the glomerular filtrate in Squalus acanthias. J. Cell. and Comp. Physiol., 1932, 1, 131:

Cope, C. L., The excretion of creatinine by the human kidney in health and in nephritis. Quart. J. Med., 1931, 24, 567.

Goldring, W., with the technical assistance of Welsh, C., The effects on renal activity of the oral administration of phlorizin in man. J. Clin. Invest., 1934, 13, 749.
Jolliffe, N., and Chasis, H., The filtration and secretion of exogenous creatinine in man. Am. J. Physiol., 1933, 104, 677.

MacKay, E. M., The relation of creatinine excretion in urine to plasma creatinine concentration. Proc. Soc. Exper. Biol. and Med., 1929-30, 27, 524.

Marshall, E. K., Jr., A comparison of the function of the glomerular and aglomerular kidney. Am. J. Physiol., 1930, 94, 1.

Marshall, E. K., Jr., The comparative physiology of the kidney in relation to theories of renal secretion. Physiol. Rev., 1934, 14, 133.

Marshall, E. K., Jr., and Crane, M. M., The secretory function of the renal tubules. Am. J. Physiol., 1924, 70, 465.

Marshall, E. K., Jr., and Grafflin, A. L., The function of the proximal convoluted segment of the renal tubule. J. Cell. and Comp. Physiol., 1932, 1, 161.

Pitts, R. F., The clearance of creatine in the phlorizinized dog. Am. J. Physiol., 1934, 109, 542.

Shannon, J. A., Absorption and excretion of water and salts by the elasmobranch fishes. IV. The secretion of exogenous creatinine by the dogfish, Squalus acanthias. J. Cell. and Comp. Physiol., 1934a, 4, 211.

Shannon, J. A., The excretion of inulin by the dogfish, Squalus acanthias. J. Cell. and Comp. Physiol., 1934b, $5,301$.

Shannon, J. A., Jolliffe, N., and Smith, H. W., The excretion of urine in the dog. VI. The filtration and secretion of exogenous creatinine. Am. J. Physiol., 1932, 102, 534.

Shannon, J. A., and Smith, H. W., The excretion of inulin, xylose and urea by normal and phlorizinized man. J. Clin. Invest., 1935, 14, 393.

White, H. L., and Monaghan, B., A comparison of the clearances of creatinine and of various sugars. Am. J. Physiol., 1933, 106, 16. 